\title{
Atomic Spectroscopy S \\ Investigation of Curcumin Role on Doxorubicin-induced Tissue Damage in Terms of Trace Metal Levels Using ETAAS
}

\author{
Olcay Kaplan Ince, ${ }^{\mathrm{a}, \mathrm{b}}$ Fatih Mehmet Kandemir, ${ }^{\mathrm{c}}$ Muharrem Ince, ${ }^{\mathrm{b}, \mathrm{d}, *}$ Fulya Benzer, Ali Onal, ${ }^{\mathrm{f}}$ and \\ Sefa Kucukler ${ }^{\mathrm{c}}$ \\ ${ }^{a}$ Munzur University, Faculty of Fine Arts, Department of Gastronomy and Culinary Arts, Tunceli, Turkey \\ ${ }^{\mathrm{b}}$ Munzur University Rare Earth Elements Application and Research Center, Tunceli, Turkey \\ ${ }^{c}$ Atatürk University, Faculty of Veterinary, Department of Biochemistry, Erzurum, Turkey \\ ${ }^{\mathrm{d}}$ Munzur University, Tunceli Vocation School, Department of Chemistry and Chemical Processes, Tunceli, Turkey \\ ${ }^{\mathrm{e}}$ Munzur University, Faculty of Health Sciences, Department of Midwifery, Tunceli, Turkey \\ ${ }^{\mathrm{f}}$ Yeditepe University, Faculty of Health Sciences, Department of Nutrition and Dietetics, Istanbul, Turkey \\ Received: Jun. 11, 2020; Revised: Jul. 16, 2020; Accepted: Jul. 16, 2020; Published: Aug. 01, 2020.
}

DOI: $10.46770 / A S .2020 .04 .006$

ABSTRACT: Doxorubicin (DXR) is one of the commonly used chemotherapeutic agents, which is highly toxic and causes gastrointestinal and cardiac toxicity. Curcumin is used as a spice and coloring agent in food, but also possesses anti-proliferating, potent antioxidant, antitumor-promoting and anti-carcinogenic properties in vitro and in vivo. In this study, the change in element concentrations in the tissues of healthy animals was examined by administering doxorubicin and curcumin separately, or both at the same time. For this purpose, 35 wistar albino male rats were selected and randomly divided into five groups of seven each. The objective of this study was to assess and compare the levels of copper, iron, zinc and selenium in the liver, kidney, heart, and testis of the control group and in the doxorubicin-induced tissues. According to the results, the $\mathrm{Cu}, \mathrm{Fe}, \mathrm{Zn}$, Se amounts and the $\mathrm{Cu} / \mathrm{Fe}$, $\mathrm{Cu} / \mathrm{Zn}$, and $\mathrm{Cu} / \mathrm{Se}$ ratios were present at different levels in each of the five groups. In terms of element concentration, the most affected tissue by doxorubicin application is the heart, and the least affected is the kidney. The ratios of $\mathrm{Cu} / \mathrm{Fe}$ and $\mathrm{Cu} / \mathrm{Se}$ in the liver and the heart were highest in Group II and Group III, respectively.

\section{INTRODUCTION}

Doxorubicin (DXR) is a cancer drug widely used for chemotherapy. ${ }^{1,2}$ Because of its cytotoxicity to normal cells or tissues, its application is clinically limited. When used long term, DXR causes various side effects, such as resistance and toxicity to normal tissues. ${ }^{3}$ To decrease DXR toxicity and improve bioavailability, various carrier systems have been developed to maintain the tumor inhibition effect. ${ }^{4-6}$ Recently, researchers have been investigating the DXR effect on normal cells or tissues. ${ }^{7}$ Others studied the common herb curcumin (CMN) known for its antioxidant activity and being anti-inflammatory, antioxidant, antiproliferative, antiangiogenic, hepatoprotective, antimetastatic, antidiabetic, antiarthritic antithrombotic, and antiatherosclerotic. ${ }^{8}$

Various preclinical studies reported that $\mathrm{CMN}$ is well known for its potential to inhibit carcinogenesis induced by chemical carcinogens, both in the initiation and progression stages. ${ }^{9}$ It also strengthens the body's defenses against reactive oxygen species by increasing the levels of other endogenous antioxidants. ${ }^{10-12}$ Curcumin shows its antioxidant properties by inhibiting reactive oxygen species production and scavenging molecular hydroxyl and oxygen radicals. It is also being used as a natural herbal remedy for treatment of inflammatory disorders and many other diseases. ${ }^{3,14}$ Curcumin has been studied together with many nephrotoxic agents, and its protective efficacy has been proven. ${ }^{15-}$

19 Extensive investigation has indicated that $\mathrm{CMN}$ enhances 
wound healing, protects from liver injury and has antiatherosclerotic activity. ${ }^{20}$

When DXR destroys the tissue or cell, enzymes are formed from trace elements such as selenium (Se), zinc $(\mathrm{Zn})$, copper $(\mathrm{Cu})$, and iron $(\mathrm{Fe})$. These play a vital role in a number of biological processes by activating or inhibiting enzymes, besides functional cofactors of various enzymes, all of which are crucial for biochemical cell activity and to maintain the integrity of various cell apparatuses. Iron is an essential nutrient for cell proliferation and growth. When Fe enters redox cycling, it becomes toxic and can initiate tumor and tumor growth because of free radical formation. It also has crucial functions in mitochondrial enzymes, deoxyribonucleic acid synthesis and the cell cycle along with the function of vital $\mathrm{Fe}$ and heme-containing enzymes. ${ }^{21}$ While $\mathrm{Fe}$ is essential for growth and the metabolism, lose electrons potentially cause deleterious free radical-generating reactions. ${ }^{22}$ Selenium (Se) is considered an essential trace element for the organism and its biological functions are mediated by approximately 20 selenoproteins that have selenocysteine in their active centers. Selenoproteins play a vital role in all tissues and are also involved in the thyroid hormone metabolism, inflammation, and immunity. In order to prevent or decrease the harmful effects of heavy metals on the antioxidant system in various tissues, Se is a wellestablished antioxidant. ${ }^{23}$ Thus, the protective effect in biological systems of various elements especially $\mathrm{Hg}^{2+}$ has been studied. ${ }^{24}$ Copper, present in all tissues and required for cellular respiration, plays a vital role in the development of the central nervous system and is a cofactor for countless enzymes. Serious damage can occur in case of excessive $\mathrm{Cu}$ intake, while if not taken in high enough amounts, it may cause incomplete human development. When $\mathrm{Cu}$ is involved in free radical production, it can result in mitochondrial damage, breakage of DNA and lead to neural harm. ${ }^{25} \mathrm{Zn}$ is another important element in the development of the rapidly growing human tissues because it is a component of DNA and ribonucleic acid (RNA) polymerase. Zinc also has a modulatory and protective action in the growth of cells. ${ }^{26,27}$

The objective of the current study was to compare trace element concentrations of a control group with DXR-induced and $\mathrm{DXR}+\mathrm{CMN}$ treated tissues. There have been few studies where trace elements were determined in control group tissues and DXRinduced tissues in rats. The concentrations of $\mathrm{Cu}, \mathrm{Zn}, \mathrm{Se}$ and $\mathrm{Fe}$ were determined in tissues from five different groups of seven rats each using electrothermal atomic absorption spectrometer (ETAAS). Finally, the $\mathrm{Cu}, \mathrm{Zn}, \mathrm{Se}$, and Fe levels were compared and evaluated with the $\mathrm{Cu} / \mathrm{Zn}, \mathrm{Cu} / \mathrm{Se}$, and $\mathrm{Cu} / \mathrm{Fe}$ ratios of the tissues in the control group and the DXR-induced tissue group.

\section{EXPERIMENTAL}

Instruments. The measurements were performed using the model AAnalyst 800 ETAAS (PerkinElmer, Inc., USA) for the determination of element concentrations. To determine $\mathrm{Cu}, \mathrm{Fe}, \mathrm{Zn}$ and Se levels, hollow cathode lamps were used. The operating conditions are listed in Table 1. A microwave digestion system (Coolpex, P. R. China) was used for tissue sample digestion.

Reagents, drugs, and standard solutions. In all experiments, the chemical reagents were of analytical reagent grade and the solutions were prepared using ultrapure water (Elga, PURELAB flex $18.2 \mu \Omega \mathrm{cm}^{-1}$ resistivity). $\mathrm{HNO}_{3}$ (E. Merck, Germany) was of ultrapure quality. Doxorubicin was purchased as Adriamycin (50 mg $25 \mathrm{~mL}^{-1}$ injectable solution, Saba, Turkey). The herb curcumin and the chemicals used were obtained from Sigma-Aldrich Chemical Company (USA). Metal stock solutions of $1000 \mathrm{mg} \mathrm{L}^{-1}$ were prepared. All standard solutions were obtained by diluting these stock solutions to obtain the calibration graphs.

Animals. Male wistar albino rats (weighing between 230-250 g each) were purchased from the Experimental Research and Application Center of Ataturk University, Turkey. The animals were housed in standard plastic cages under well-regulated conditions (relative humidity range: $45 \% \pm 5$, temperature: $24 \pm 1{ }^{\circ} \mathrm{C}$, and a $12 \mathrm{~h}$ light $/ 12 \mathrm{~h}$ dark cycle). Their diet consisted of standard pellet feed and tap water. The experiments were designed and conducted according to ethical norms as approved by the Local Animal Care Committee of Ataturk University, Erzurum, Turkey (Protocol No: 2016-8/164).

Experimental Protocol. Thirty-five wistar albino male rats were randomly divided into five groups of seven rats in each group.

Table 1. Instrumental Operating Conditions of Analyst 800 ETAAS

\begin{tabular}{|c|c|c|c|c|c|c|c|c|c|c|c|c|}
\hline \multirow{2}{*}{ Step } & \multicolumn{4}{|c|}{ Temperature $\left({ }^{\circ} \mathrm{C}\right)$} & \multicolumn{4}{|c|}{ Ramp Time (s) } & \multicolumn{4}{|c|}{ Hold Time (s) } \\
\hline & $\mathbf{C u}$ & $\mathrm{Fe}$ & $\mathbf{Z n}$ & $\mathrm{Se}$ & $\mathbf{C u}$ & $\mathbf{F e}$ & $\mathbf{Z n}$ & Se & $\mathbf{C u}$ & $\mathbf{F e}$ & $\mathbf{Z n}$ & $\mathrm{Se}$ \\
\hline Dry 1 & 110 & 110 & 110 & 110 & 1 & 1 & 1 & 1 & 30 & 30 & 30 & 30 \\
\hline Dry 2 & 140 & 130 & 130 & 130 & 10 & 15 & 15 & 15 & 25 & 30 & 30 & 30 \\
\hline Pyrolysis & 1100 & 1400 & 700 & 1300 & 10 & 10 & 10 & 10 & 30 & 20 & 20 & 20 \\
\hline Atomization & 2300 & 2100 & 1500 & 1900 & 0 & 0 & 0 & 0 & 5 & 5 & 5 & 5 \\
\hline \multirow[t]{2}{*}{ Clean-out } & 2450 & 2450 & 2450 & 2450 & 2 & 1 & 1 & 1 & 5 & 3 & 3 & 3 \\
\hline & & & & & \multicolumn{2}{|c|}{$\mathbf{C u}$} & \multicolumn{2}{|c|}{$\mathbf{F e}$} & \multicolumn{2}{|c|}{$\mathbf{Z n}$} & \multicolumn{2}{|c|}{ Se } \\
\hline \multicolumn{5}{|c|}{ Wavelength $(\lambda, \mathbf{n m})$} & \multicolumn{2}{|c|}{324.8} & \multicolumn{2}{|c|}{248.3} & \multicolumn{2}{|c|}{213.9} & \multicolumn{2}{|c|}{196.0} \\
\hline \multicolumn{5}{|c|}{ Hollow cathode lamp current (mA) } & \multicolumn{2}{|c|}{30.0} & \multicolumn{2}{|c|}{30.0} & \multicolumn{2}{|c|}{20.0} & \multicolumn{2}{|c|}{16.0} \\
\hline \multicolumn{5}{|c|}{ Injection volume $(\mu \mathrm{L})$} & \multicolumn{2}{|c|}{20} & \multicolumn{2}{|c|}{20} & \multicolumn{2}{|c|}{20} & \multicolumn{2}{|c|}{20} \\
\hline \multicolumn{5}{|c|}{ Slit width $(\mathrm{nm})$} & \multicolumn{2}{|c|}{0.7} & \multicolumn{2}{|c|}{0.2} & \multicolumn{2}{|c|}{0.7} & \multicolumn{2}{|c|}{2.0} \\
\hline \multicolumn{5}{|l|}{ LOD $\left(\mu \mathrm{g} \mathrm{kg}^{-1}\right)$} & \multicolumn{2}{|c|}{0.5} & \multicolumn{2}{|c|}{0.3} & \multicolumn{2}{|c|}{0.1} & \multicolumn{2}{|c|}{0.02} \\
\hline $\operatorname{LOQ}\left(\mu \mathrm{g} \mathrm{kg}^{-1}\right.$ & & & & & \multicolumn{2}{|c|}{1.5} & \multicolumn{2}{|c|}{0.9} & & & & \\
\hline
\end{tabular}


Group I (Control): Normal saline orally for 7 days. Group II: CMN (200 $\mathrm{mg} \mathrm{kg}^{-1}$ body weight (b.wt.)/day) was administered orally for 7 days. Group III: A single dose of DXR (40 $\left.\mathrm{mg} \mathrm{kg}^{-1}\right)$ was injected intraperitoneally into the rats on the 5th day. Group IV: A single dose of DXR (40 mg kg-1) on the 5th day of treatment schedule along with daily administration of CMN (100 mg kg-1 b.wt./day) for 7 days. Group V: A single dose of DXR (40 mg/kg) on the 5th day of treatment schedule along with daily administration of CMN (200 $\mathrm{mg} \mathrm{kg}^{-1}$ b.wt./day) for 7 days. After 24 hours from final CMN administration, the rats were sacrificed under mild sevoflurane anesthesia (Sevorane liquid 100\%, Abbott Laboratory, Istanbul, Turkey). At the end of the study, the tissues from the liver, kidney, heart, and testis were analyzed.

Analytical Procedure for Elemental Analysis. Homogenized tissue samples of about $0.2 \mathrm{~g}$ were taken into Teflon vessels. After this processes, $5 \mathrm{~mL}$ concentrated $\mathrm{HNO}_{3}$ was added and resolubilized by microwave digestion. To obtain clear solutions, the final volume was completed to $10 \mathrm{~mL}$ ultrapure water. The analyses were prepared in triplicate. The blank solutions were carried out in the same way. The concentration of elements including $\mathrm{Cu}, \mathrm{Fe}, \mathrm{Zn}$ and Se were based on the calibration curves. The calibration curves were constructed by plotting the absorption (y) against the concentration of each element (x). Obtained and used calibration graphs were linear between studied ranges. Based on the linear equations, the $\mathrm{R}^{2}$ values were obtained as 0.998 for $\mathrm{Cu}, 0.0999$ for Fe, 0.996 for $\mathrm{Zn}$ and 0.999 for Se. Also, the LOD and LOQ values of the elements were calculated and are presented in Table 1.

Statistical Analysis. SPSS software Version 24 (SPSS Inc., USA) was used for the analysis of all data. One-way analysis of variance was carried out. When $\mathrm{p}<0.05$ was achieved, the results were considered significantly different. All data were checked in terms of equal variance and normal distribution. Differences between the means were assessed using Tukey's Honest Significant Difference test for post hoc multiple comparisons. The values were presented as the mean \pm standard deviation.

\section{RESULTS AND DISCUSSION}

The effect of DXR and CMN alone or in combination with elemental levels according to the control group was examined separately for liver, heart, kidney, and testicular tissues (Table 2). When comparing Group I with Group IV, it was found that DXR and $\mathrm{CMN}$ treatment affected the $\mathrm{Fe}, \mathrm{Zn}$ and Se levels in the liver and heart tissues; the $\mathrm{Cu}$ and Fe levels in the kidney tissues, and the Fe and Se levels in the testis tissues. When comparing Group I with Group II, the CMN treatment did not cause changes in the liver and testis, but it changed the Fe and Se levels in the heart, and only the Fe level in the kidney tissue. When comparing Group I with Group III, the DXR application caused changes in the levels of $\mathrm{Zn}$ and $\mathrm{Se}$ in the liver, the $\mathrm{Cu}, \mathrm{Fe}$, and $\mathrm{Zn}$ levels in the heart, and the Fe levels in the testis, but did not cause any changes in the elemental levels of the kidneys. When comparing Group I with Group V, it was found that the $\mathrm{Zn}$ levels in the liver; the $\mathrm{Cu}, \mathrm{Fe}, \mathrm{Se}$ levels in the heart; the $\mathrm{Cu}$ and Fe levels in the kidney; and the $\mathrm{Cu}$, $\mathrm{Fe}, \mathrm{Zn}$ and Se levels in the testis were influenced by DXR and CMN treatment.

It is most noteworthy that in terms of elemental concentration, the most affected tissue by DXR application is the heart, and the least affected tissue is the kidney. Since $\mathrm{Fe}$ is a prooxidant substance, the application of CMN causes a decrease in the Fe level, and its strength can be interpreted as an antioxidant.

Table 2. Comparison of the Elemental Concentrations in the Tissues of the Five Groups

\begin{tabular}{|c|c|c|c|c|c|}
\hline & \multicolumn{5}{|c|}{ Concentration, mg kg-1 } \\
\hline & Group & $\mathbf{C u}$ & $\mathbf{F e}$ & Zn & Se \\
\hline \multirow{5}{*}{ Liver } & $\mathbf{I}$ & $3.46 \pm 0.08 \mathrm{ab}$ & $480.95 \pm 12.60 \mathrm{bc}$ & $26.85 \pm 0.13 \mathrm{c}$ & $0.98 \pm 0.06 \mathrm{~b}$ \\
\hline & II & $3.63 \pm 0.08 \mathrm{ab}$ & $425.08 \pm 16.94 \mathrm{c}$ & $26.04 \pm 0.48 \mathrm{c}$ & $0.97 \pm 0.03 \mathrm{~b}$ \\
\hline & III & $4.12 \pm 0.47 \mathrm{a}$ & $529.50 \pm 4.95 \mathrm{ab}$ & $35.33 \pm 0.49 \mathrm{a}$ & $0.63 \pm 0.02 \mathrm{c}$ \\
\hline & IV & $3.12 \pm 0.23 \mathrm{~b}$ & $581.30 \pm 62.01 \mathrm{a}$ & $29.80 \pm 1.12 b$ & $1.18 \pm 0.04 \mathrm{a}$ \\
\hline & $\mathbf{V}$ & $3.49 \pm 0.09 \mathrm{ab}$ & $454.88 \pm 16.31 \mathrm{bc}$ & $36.13 \pm 0.82 \mathrm{a}$ & $1.02 \pm 0.04 \mathrm{~b}$ \\
\hline \multirow{5}{*}{ Heart } & $\mathbf{I}$ & $4.48 \pm 0.15 \mathrm{c}$ & $272.79 \pm 29.10 \mathrm{a}$ & $19.16 \pm 0.28 \mathrm{a}$ & $0.35 \pm 0.02 \mathrm{c}$ \\
\hline & II & $4.57 \pm 0.05 \mathrm{bc}$ & $579.08 \pm 0.01 \mathrm{c}$ & $19.29 \pm 0.15 \mathrm{a}$ & $0.78 \pm 0.04 \mathrm{a}$ \\
\hline & III & $4.92 \pm 0.08 \mathrm{a}$ & $127.93 \pm 8.97 \mathrm{~b}$ & $17.82 \pm 0.11 \mathrm{~b}$ & $0.33 \pm 0.02 \mathrm{c}$ \\
\hline & IV & $4.49 \pm 0.01 \mathrm{c}$ & $106.39 \pm 2.44 \mathrm{~b}$ & $17.19 \pm 0.30 \mathrm{~b}$ & $0.84 \pm 0.06 \mathrm{a}$ \\
\hline & $\mathbf{V}$ & $4.84 \pm 0.15 \mathrm{ab}$ & $123.96 \pm 3.01 \mathrm{~b}$ & $19.91 \pm 0.44 \mathrm{a}$ & $0.52 \pm 0.01 \mathrm{~b}$ \\
\hline \multirow{5}{*}{ Kidney } & $\mathbf{I}$ & $7.27 \pm 0.25 \mathrm{~b}$ & $166.32 \pm 3.65 \mathrm{c}$ & $24.57 \pm 1.03 \mathrm{ab}$ & $1.25 \pm 0.17 \mathrm{a}$ \\
\hline & II & $6.92 \pm 0.09 \mathrm{~b}$ & $528.19 \pm 0.93 \mathrm{a}$ & $23.06 \pm 0.30 \mathrm{~b}$ & $1.30 \pm 0.12 \mathrm{a}$ \\
\hline & III & $6.92 \pm 0.15 \mathrm{~b}$ & $175.87 \pm 0.87 \mathrm{c}$ & $25.68 \pm 0.16 \mathrm{ab}$ & $1.16 \pm 0.08 \mathrm{a}$ \\
\hline & IV & $8.70 \pm 0.30 \mathrm{a}$ & $278.39 \pm 2.97 \mathrm{~b}$ & $26.26 \pm 1.12 \mathrm{a}$ & $1.19 \pm 0.05 \mathrm{a}$ \\
\hline & $\mathbf{V}$ & $1696 \pm 88 \mathrm{c}$ & $35.487 \pm 0.69 \mathrm{~d}$ & $23.83 \pm 0.97 \mathrm{ab}$ & $1.21 \pm 0.07 \mathrm{a}$ \\
\hline \multirow{5}{*}{ Testis } & I & $1.60 \pm 0.01 \mathrm{~b}$ & $14.95 \pm 0.26 \mathrm{~b}$ & $25.12 \pm 0.53 b$ & $1.28 \pm 0.11 \mathrm{~b}$ \\
\hline & II & $1.55 \pm 0.11 \mathrm{~b}$ & $15.09 \pm 0.07 \mathrm{~b}$ & $26.15 \pm 1.94 \mathrm{ab}$ & $1.20 \pm 0.09 \mathrm{~b}$ \\
\hline & III & $1.56 \pm 0.01 \mathrm{~b}$ & $11.47 \pm 0.16 \mathrm{c}$ & $24.22 \pm 0.40 \mathrm{~b}$ & $1.21 \pm 0.07 \mathrm{~b}$ \\
\hline & IV & $1.34 \pm 0.05 \mathrm{~b}$ & $11.23 \pm 0.04 \mathrm{c}$ & $22.20 \pm 1.44 \mathrm{~b}$ & $1.60 \pm 0.05 \mathrm{a}$ \\
\hline & $\mathbf{V}$ & $8.26 \pm 0.37 \mathrm{a}$ & $275.01 \pm 1.16 \mathrm{a}$ & $29.68 \pm 1.29 \mathrm{a}$ & $1.85 \pm 0.12 \mathrm{a}$ \\
\hline
\end{tabular}

Different letters within columns indicate significant differences between means $(\mathrm{p}<0.05)$. 
Table 3. Elemental Ratios in Rat Tissues

\begin{tabular}{|c|c|c|c|c|c|c|c|c|c|c|c|}
\hline \multicolumn{3}{|c|}{ Liver } & \multicolumn{3}{|c|}{ Heart } & \multicolumn{3}{|c|}{ Kidney } & \multicolumn{3}{|c|}{ Testis } \\
\hline $\mathbf{C u} / \mathbf{F e}$ & $\mathrm{Cu} / \mathbf{Z n}$ & $\mathrm{Cu} / \mathrm{Se}$ & $\mathrm{Cu} / \mathbf{F e}$ & $\mathrm{Cu} / \mathbf{Z n}$ & $\mathrm{Cu} / \mathrm{Se}$ & $\mathrm{Cu} / \mathrm{Fe}$ & $\mathrm{Cu} / \mathrm{Zn}$ & $\mathrm{Cu} / \mathrm{Se}$ & $\mathrm{Cu} / \mathrm{Fe}$ & $\mathrm{Cu} / \mathrm{Zn}$ & $\mathrm{Cu} / \mathrm{Se}$ \\
\hline 0.0072 & 0.129 & 3.54 & 0.016 & 0.233 & 12.69 & 0.043 & 0.296 & 5.81 & 0.106 & 0.063 & 1.25 \\
\hline 0.0085 & 0.139 & 3.75 & 0.078 & 0.237 & 5.85 & 0.013 & 0.299 & 5.33 & 0.103 & 0.059 & 1.29 \\
\hline 0.0077 & 0.116 & 6.49 & 0.038 & 0.276 & 14.99 & 0.039 & 0.269 & 5.97 & 0.136 & 0.064 & 1.29 \\
\hline 0.0053 & 0.104 & 2.65 & 0.042 & 0.261 & 5.32 & 0.031 & 0.331 & 7.34 & 0.119 & 0.060 & 0.83 \\
\hline 0.0060 & 0.096 & 3.41 & 0.039 & 0.243 & 9.38 & 0.048 & 0.071 & 1.39 & 0.030 & 0.278 & 4.46 \\
\hline
\end{tabular}

Since Se is particularly involved in the structure of GSH-Px from antioxidant enzymes, it can be considered the reason for the increase of Se in the liver and heart tissues. The statistically important increase of $\mathrm{Cu}$, which is a prooxidant substance, in the heart and a not statistically important increase in the liver can be explained by the detrimental effect of DXR.

The $\mathrm{Cu} / \mathrm{Fe}, \mathrm{Cu} / \mathrm{Zn}$ and $\mathrm{Cu} / \mathrm{Se}$ ratios are listed in Table 3. The $\mathrm{Cu} / \mathrm{Fe}$ ratio in the liver and the heart was highest in Group II, in the kidney in Group V, and in the testis in Group III. The liver tissue Group II, the heart Group III, the kidney Group IV, and the testis Group V had the maximum $\mathrm{Cu} / \mathrm{Zn}$ ratio. The $\mathrm{Cu} / \mathrm{Se}$ ratio of liver and heart was high in Group III, the $\mathrm{Cu} / \mathrm{Se}$ ratio of kidney was high in Group IV, and the $\mathrm{Cu} / \mathrm{Se}$ ratio of testis was high in Group V.

Briefly, while DXR administration was compared with the control group, there was no statistically significant difference in the levels of elements in the kidney tissue, only the Fe level in the testis tissue changed, as did the $\mathrm{Zn}$ and Se levels in the liver tissue and the $\mathrm{Cu}, \mathrm{Fe}$ and $\mathrm{Zn}$ levels in the heart tissue. From the perspective of the tissues, the most affected tissue from DXR is the heart tissue, and the least affected is the kidney tissue. When the control group is compared to Group II which was administered $\mathrm{CMN}$, it affected the Fe and Se levels in the heart tissue and affected only the $\mathrm{Fe} / \mathrm{Zn}$ ratio in the kidney tissue Fe level.

There have also been many other studies and various results were reported about heavy metal levels in tissues. Al-Ebraheem et al. investigated the metal levels of $\mathrm{Cu}, \mathrm{Zn}, \mathrm{K}$ and $\mathrm{Fe}$ in normal and malignant liver and kidney tissue by X-ray fluorescence. ${ }^{28}$ They stated that while $\mathrm{Zn}$ was reduced in liver and kidney tumors, the elements $\mathrm{Fe}, \mathrm{Cu}$ and $\mathrm{K}$ increased in kidney tumors, and $\mathrm{Ca}, \mathrm{Fe}, \mathrm{Cu}$ and $\mathrm{Zn}$ also increased in the malignant area. Bargellini et al. investigated the relationship between trace elements, immune parameters, and human cancer. ${ }^{29}$ They stated that there is an interesting association between the state of anxiety and $\mathrm{Cu}$, in addition to a high association between anxiety and glutathione peroxidase. The elemental levels found in human hair were compared between breast cancer and healthy individuals by Benderli Cihan et al..$^{30}$ Based on their results, while the Fe level was at a higher average in the patients, the Ca level was at a higher average in the controls. On the other hand, the $\mathrm{Mg}, \mathrm{Zn}$, and $\mathrm{Na}$ concentrations had increased in both the patient and the control groups. Furthermore, almost all element values in the cancer patients showed higher dispersion and asymmetry than in the healthy controls. Between patients and controls, there were statistically significant differences in the concentrations of $\mathrm{Zn}$, Se, $\mathrm{Ca}$ and $\mathrm{Mn}(\mathrm{p}<0.05)$.

Ebrahim et al. investigated some trace element levels in Sudanese patients with confirmed breast cancer. ${ }^{31}$ To determine the $\mathrm{Fe}, \mathrm{Se}, \mathrm{Zn}$, and Sc levels in these subjects, neutron activation analysis was used. They stated that the levels of Se and $\mathrm{Zn}$ in malignant tissues were significantly elevated $(p<0.05)$ in comparison to the normal tissues. X-ray fluorescence spectroscopy was used by Wandzilak et al. to determine the concentration of elements in neoplastic and healthy brain tissues. ${ }^{32}$ They made a map of various elements including $\mathrm{Cu}, \mathrm{Zn}, \mathrm{P}, \mathrm{S}, \mathrm{Ca}$, and $\mathrm{Fe}$ for cancerous tissues. Using these maps, the concentration levels of elements in brain tissue were compared between malignant tissue and controls. According to the results of this study, the average concentrations of $\mathrm{Ca}, \mathrm{P}, \mathrm{S}$ and $\mathrm{Fe}$ decreased in malignant tissues in comparison to the control group, whereas the $\mathrm{Zn}$ level in these tissues increased. The results revealed that $\mathrm{Zn}$, $\mathrm{Cu}, \mathrm{Fe}, \mathrm{Ca}$, and $\mathrm{K}$ play an important role for tissue classification.

The blood $\mathrm{Cu}, \mathrm{Zn}, \mathrm{Se}$, and $\mathrm{Cd}$ levels were investigated in breast cancer patients by Saleh et al. using spectrophotometry. ${ }^{33}$ Based on their findings, the $\mathrm{Cu}$, Se and $\mathrm{Zn}$ levels in breast cancer patients were significantly lower than in the controls, while the $\mathrm{Cd}$ level was significantly $(\mathrm{p}<0.0001)$ higher in the patients than in the controls. Kiziler et al. examined the effects of $\mathrm{Cu}, \mathrm{Fe}$ and $\mathrm{Zn}$ levels on the development, progression, and histology of prostate cancer. They observed that the level of these elements' changes in the serum prostate tissues. ${ }^{34}$ From the Pearson correlation, the serum $\mathrm{Cu} / \mathrm{Zn}$ ratio significantly and positively correlated with serum. A significant positive correlation was found between tissue $\mathrm{Cu} / \mathrm{Zn}$ and tissue $\mathrm{Fe} / \mathrm{Zn}$ in malignant tissue. Lin et al. measured trace elements in patients with bladder cancer and a healthy group using a graphite furnace atomic absorption spectrophotometer. ${ }^{35}$ According to obtained data, while the urinary $\mathrm{Zn}$ and Se mean values in patients were significant $(\mathrm{p}<0.05)$ and their levels higher than the controls, urinary $\mathrm{Cu}, \mathrm{As}$ and $\mathrm{Pb}$ were not significantly different. But no significant differences were found in terms of the $\mathrm{Cu}, \mathrm{Pb}$ and as values between patients and controls. However, in the bladder cancer urine, the $\mathrm{Pb}$ levels were elevated by about $40 \%$. They reported that the Se and $\mathrm{Zn}$ levels are associated with the proliferation of bladder cancer cells and are excreted in the urine of bladder cancer patients. Ceruloplasmin (Cp), transferrin (Trf), albumin, and the $\mathrm{Fe}, \mathrm{Zn}, \mathrm{Mg}, \mathrm{Cu} \mathrm{Mn}$ levels in serum in laryngeal carcinoma were examined by Taysi et al. ${ }^{36}$ Although the 
concentrations of $\mathrm{Fe}$ and $\mathrm{Mn}$ serum were higher in the control group than in the laryngeal cancer groups, the difference was not statistically significant $(p>0.05)$. When compared to the control group, lower $\operatorname{Trf}(\mathrm{p}<0.01), \mathrm{Zn}(\mathrm{p}<0.01)$ and $\mathrm{Mg}(\mathrm{p}<0.001)$ and higher $\mathrm{Cp}(\mathrm{p}<0.01)$ and $\mathrm{Cu}(\mathrm{p}<0.001)$ concentrations were found in the laryngeal cancer groups.

\section{CONCLUSIONS}

It can be stated that there are negative as well as positive effects caused by drugs, such as DXR, used in the treatment of cancer, which is becoming ever more widespread. This study is first in reporting the results of an experiment where a healthy animal was administered DXR alone, CMN alone, and CMN and DXR together, and the changes in trace element concentrations found in liver, kidney, heart, and, testis tissues. According to the obtained data, the effects of these chemicals on the element concentrations in each of the tissues were different. The heart tissue was the most affected tissue with DXR, and the kidney was least affected by this drug.

\section{AUTHOR INFORMATION}

\section{Corresponding Author}

*M. Ince

Email address: muharremince@munzur.edu.tr

\section{Notes}

The authors declare no competing financial interest.

\section{ACKNOWLEDGMENTS}

Ethical Approval. All applicable international, national, and institutional guidelines for the care and use of animals were followed. The experiments were designed and conducted according to ethical norms approved by the Local Animal Care Committee of Ataturk University, Erzurum, Turkey (Protocol No: 2016-8/164).

\section{REFERENCES}

1. T. Minko, E. V. Batrakova, S. Li, Y. L. Li, R. I. Pakunlu, V. Y. Alakhov, and A. V. Kabanov, J. Control. Release., 2005, 105, 269-278. https://doi.org/10.1016/j.jconrel.2005.03.019

2. P. S. Lai, P. J. Lou, C. L. Peng, C. L. Pai, W. N. Yen, M. Y. Huang, T. H. Young, and M. J. Shieh, J. Control. Release., 2007, 122, 39-46. https://doi.org/10.1016/j.jconrel.2007.06.012

3. L. A. Smith, V. R. Cornelius, C. J. Plummer, G. Levitt, M. Verill, P. Canne, and A. Jones, BMC Cancer, 2010, 10, 337. https://doi.org/10.1186/1471-2407-10-337
4. Y. J. Wang, V. Bansal, A. N. Zelikin, and F. Caruso, Nano. Lett., 2008, 8, 1741-1745. https://doi.org/10.1021/n1080877c

5. K. Kono, C. Kojima, N. Hayashi, E. Nishisaka, K. Kiura, S. Wataral, and A. Harada, Biomaterials, 2008, 29, 1664-1675. https://doi.org/10.1016/j.biomaterials.2007.12.017

6. Y. Wang, X. Cao, R. Guo, M. Shen, M. Zhang, M. Zhu, and X. Shi, Polym. Chem., 2011, 2, 1754-1760. https://doi.org/10.1039/C1PY00179E

7. J. Zhu, L. Liao, X. Bian, X. Kong, P. Yang and B. Liu, Small, 2012, 8, 2715-2720. https://doi.org/10.1002/smll.201200217

8. P. Anand, S. G. Thomas, A. B. Kunnumakkara, C. Sundaram, K. B. Harikumar, B. Sung, S. T. Tharakan, K. Misra, I. K. Priyadarsini, K. N. Rajasekharan, and B. B. Aggarwal, Biochem. Pharmacol., 2008, 76, 1590-1611. https://doi.org/10.1016/j.bcp.2008.08.008

9. R. L. Thangapazham, A. Sharma, and R. K. Maheshwari, AAPS J., 2006, 8, E443-9. https://doi.org/10.1208/aapsj080352

10. E. Balogun, M. Hoque, P. Gong, E. Killeen, C. J. Green, R. Foresti, J. Alam, and R. Motterlini, Biochem. J., 2003, 371, 887-895. https://doi.org/10.1042/bj20021619

11. S. S. Bansal, M. Goel, F. Aqil, M. V. Vadhanam, and R. C. Gupta, Cancer Prev. Res., 2011, 4, 1158-1171. https://doi.org/10.1158/1940-6207

12. A. H. Rahmani, M. A. Al Zohairy, S. M. Aly, and M. A. Khan, Biomed. Res. Int., 2014, 15, 761608. https://doi.org/10.1155/2014/761608

13. N. Sreejayan and M. N. Rao, Arzneimittelforschung, 1996, 46, 169-171.

14. R. A. Sharma, A. J. Gescher, and W. P. Steward, Eur. J. Cancer, 41, 1955-1968. https://doi.org/10.1016/j.ejca.2005.05.009

15. A. Duvoix, R. Blasius, S. Delhalle, M. Schnekenburger, F. Morceau, E. Henry, M. Dicato, and M. Diederich, Cancer Lett., 2005, 223, 181-190. https://doi.org/10.1016/j.canlet.2004.09.041

16. S.-X. Cui, X.-J. Qu, Y.-Y. Xie, L. Zhou, M. Nakata, M. Makuuchi, and W. Tang, Int. J. Mol. Med., 2006, 18, 227-231. https://doi.org/10.3892/ijmm.18.2.227

17. J. Trujillo, Y. I. Chirino, E. Molina-Jijón, A. C. Andéricaromero, E. Tapia, and J. Pedraza-Chaverrí, Redox Biol.,2013, 1, 448-456. https://doi.org/10.1016/j.redox.2013.09.003

18. M. Buyuklu, F. M. Kandemir, M. Ozkaraca, T. Set, E. M. Bakirci, and E. Topal, Eur. Rev. Med. Pharmacol. Sci., 2014, 18, 461-470.

19. M. Mohajeri, M. Rezaee, and A. Sahebkar, BioFactors, 2017, 43, 645-661. https://doi.org/10.1002/biof.1376

20. S. Shishodi, M. M. Chaturvedi, and B. B. Aggarwal, Curr. Probl. Cancer, 2007, 31, 243-305. https://doi.org/10.1016/j.currproblcancer.2007.04.001

21. R. Crichton, Iron metabolism: From molecular mechanisms to cinical consequences, $3^{\text {rd }}$, John Wiley and Sons, 2009, https://doi.org/10.1002/9780470010303

22. S. V. Torti and F. M. Torti, Nat. Rev. Cancer, 2013, 13, 342-355. https://doi.org/10.1038/nrc3495

23. H.-D. Yao, Q. Wu, Z.-W. Zhang, J.-L. Zhang, S. Li, J.-Q. Huang, F.-Z. Ren, S.-W. Xu, X.-L. Wang, and X.G. Lei, J. Nutr., 2013, 143, 613-619. https://doi.org/10.3945/jn.112.172395

24. M. Xing, X. Jin, J. Wang, Q. Shi, J. Cai, and S. Xu, Biol. Trace Elem. Res., 2018, 185, 162-169. https://doi.org/10.1007/s12011-017-1200-2

25. V. Desai and S. G. Kaler, Am. J. Clin. Nutr., 2008, 88, 855S-858S. https://doi.org/10.1093/ajen/88.3.855S

26. P. Travglini, P. Moriondo, and E. Togni, J. Clin. Endocrinol. Metab., 
1989, 68, 186-190. https://doi.org/10.1210/jcem-68-1-186

27. V. Singh and A. N. Garg, Biol. Trace Elem. Res., 1998, 64, 237-245. https://doi.org/10.1007/BF02783340

28. A. Al-Ebraheem, M. J. Farquharson, and E. Ryan, Appl. Radiat. Isot., 2009, 67, 470-474. https://doi.org/10.1016/j.apradiso.2008.06.018

29. A. Bargellini, L. Piccinini, M. De Palma, P. Giacobazzi, S. Scaltriti, M. Mariano, R. Roncaglia, and P. Borella, J. Trace Elem. Med. Biol., 2003, 17, 3-9. PMID: 14650622

30. Y. Benderli Cihan, S. Sözen, and S. Öztürk Yıldırım, Biol. Trace Elem. Res., 2011, 144, 360-379. https://doi.org/10.1007/s12011-0119104-z

31. A. M. Ebrahim, M. A. H. Eltayeb, M. K. Shaat, N. M. A. Mohmed, E. A. Eltayeb, and A. Y. Ahmed, Sci. Total Environ., 2007, 383, 52-58. https://doi.org/10.1016/j.scitotenv.2007.04.047
32. A. Wandzilak, M. Czyzycki, E. Radwanska, D. Adamek, K. Geraki, and M. Lankosz, Spectrochim. Acta Part B., 2015, 114, 52-57. https://doi.org/10.1016/j.sab.2015.10.002

33. F. Saleh, A. Behbehani, S. Asfar, I. Khan, and G. Ibrahim, Biol. Trace Elem. Res., 2011, 141, 96-109. https://doi.org/10.1007/s12011-010-8724-Z

34. A. R. Kiziler, B. Aydemir, S. Guzel, B. Alici, S. Ataus, M. B. Tuna, H. Durak, and M. Kilic, Trace Elem. Electroly., 2010, 27(2), 65-72. https://doi.org/10.5414/TEP27065

35. C.-N. Lin, L.-H. Wang, and K.-H. Shen, J. Clin. Lab. Anal., 2009, 23, 192-195. https://doi.org/10.1002/jcla.20318

36. S. Taysi, F. Akcay, C. Uslu, Y. Dogru, and I. Gulcin, Biol. Trace Elem. Res., 2003, 91, 11-18. https://doi.org/10.1385/BTER:91:1:11

\section{CRC Press/Routledge/Taylor \& Francis announces the availability of:}

\section{Measuring Heavy Metal Contaminants in Cannabis and Hemp}

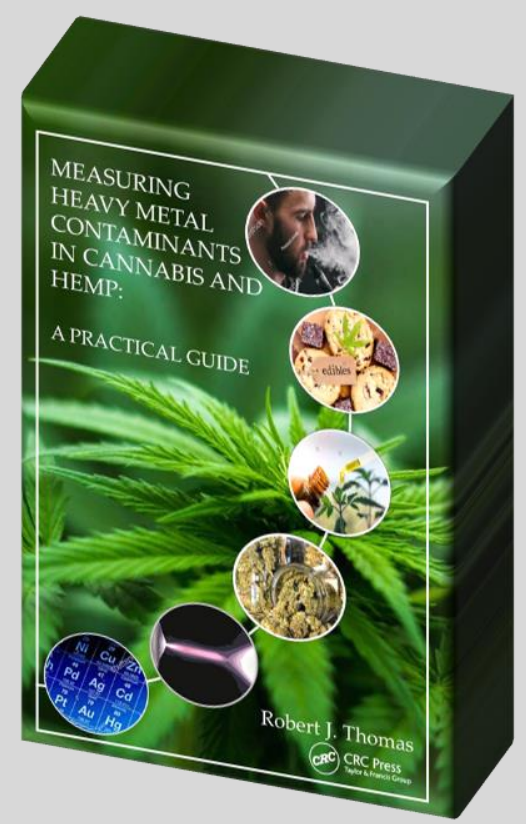

Available September, 2020

ISBN: 9780367417376
Robert J. Thomas, CSci, CChem, FRSC Principal Consultant

Scientific Solutions, Gaithersburg, MD

www.scientificsolutions1.com

The complete guide to measuring elemental contaminants in cannabis and hemp for growers, cultivators, processors, testing labs and regulators.

Offers guidance to cultivators and processors to better understand the sources of heavy metals in cannabis.

For state regulators, it compares maximum contaminant limits of heavy metals with those for federally-regulated pharmaceutical materials.

For testing labs, it describes fundamental principles and practical capabilities of ICP-MS, ICP-OES, AA and AF for measuring heavy metals in cannabis.

Suggests strategies to characterize heavy metals in vaping liquids and aerosols

- Covers the important role of other analytical techniques for the comprehensive testing of cannabis products 